\title{
Examining privilege and power in US urban parks and open space during the double crises of antiblack racism and COVID-19
}

\author{
Fushcia -Ann Hoover ${ }^{1}$. Theodore C. Lim²
}

Received: 31 July 2020 / Accepted: 17 October 2020

(c) Springer Nature Singapore Pte Ltd. 2020

\begin{abstract}
In this perspective, we argue that creating the positive outcomes socio-ecological researchers and practitioners seek for urban areas requires acknowledging and addressing the interactions of race and systemic racism in parks, open and green spaces. Racial experiences are inseparable from physical landscapes and the processes of designing, managing, or studying them. From COVID-19 to the Black Lives Matter movement and protests, the events of 2020 in the United States underscore how considerations of social justice must extend beyond the conventional distributional focus of environmental justice. It must incorporate an understanding of how the built environment is racialized spatially, but not always readily quantified through the proximity-based measurements frequently used in research and practice. The perspective is organized in three main parts. The first part presents a series of vignettes to frame the ways cities and individuals participate, respond, and interact under COVID-19 with racial segregation as the backdrop. The second part suggests a stepwise approach to building an understanding of racial inequities in socio-ecological systems (SES) research and practice including four entry points: (1) racialized spatial distribution of hazards and amenities, (2) racialized qualities of space, (3) racialized people in space, and (4) racialized creation of space. Finally, the third part proposes actions the SES community can take to enhance our commitment to community recovery, improvement, and thrivability. This perspective cautions practitioners and researchers against opportunistic or quick-fix solutions, and instead challenges our colleagues to be inclusive of disenfranchised voices in shaping socio-ecological goals, now more than ever. The goal of this perspective is to spark engagement with power and privilege in parks and open space using the example of COVID-19 and race in the US.
\end{abstract}

Keywords COVID-19 $\cdot$ Race $\cdot$ Parks $\cdot$ Open space $\cdot$ Environmental justice $\cdot$ Cities

\section{The United States in crisis}

We are in the midst of two concurrent crises in the United States. The first, the novel coronavirus and its disease, COVID-19, spread across the country, as it has much of the world. However, in the US its spread initially went

F.-A. Hoover and T. C. Lim contributed equally to the conception and writing of this manuscript

Theodore C. Lim

tclim@vt.edu

Fushcia -Ann Hoover

fhoover@sesync.org

1 National Socio-Environmental Synthesis Center, 1 Park P1 Suite 300, Annapolis, MD 21401, USA

2 Urban Affairs and Planning, Architecture Annex \#207, 140 Otey St., Virginia Tech, Blacksburg, VA 24060, USA unrecognized as a concern by our institutions until March of 2020, months after its first appearance in the country. Within a matter of weeks, schools and jobs moved online, businesses closed their doors, and millions filed for unemployment (Kochhar 2020). Subsequently, what most consider an inadequate national-level coordination of the COVID response in the US has also led to continued spread of the virus (Forester and McKibben 2020). As of September 1, 2020, over 6 million Americans have been infected with the coronavirus, and over 180,000 have died.

During the same time, three horrific murders of Black Americans-Ahmad Arberry (Feb 23, 2020 in Glynn County, Georgia), Breonna Taylor (Mar 13, 2020 in Louisville, Kentucky), and George Floyd (May 25, 2020 in Minneapolis, Minnesota)—and the shooting of Jacob Blake (August 23, 2020 in Kenosha, Wisconsin), sparked protests against police brutality and antiblack racism. This second crisis of state-sanctioned violence against Black Americans 
is not new, but like COVID-19, institutions and white Americans specifically, have been slow to recognize this crisis. To date, the US National Guard has been deployed in 31 states and the District of Columbia in response to the protests, statues honoring the purveyors of colonialism and racism are toppling, and calls to defund police have intensified, as Black people (particularly Black trans women) continue to be murdered, assaulted and abused (Burns 2020). There has also been global solidarity for the Black Lives Matter movement (BLM), which originally began in 2013 in response to the acquittal of George Zimmerman, who murdered Trayvon Martin, a Black teenager walking home from the store (https ://blacklivesmatter.com/). It has since grown into a global decentralized movement against the oppression of Black people. In 2020 especially, the movement has seen a surge in global support. Between May 25, 2020 and September 1, 2020, 4437 cities and towns held Black Lives Matter protests, distributed across every inhabited continent (https:// www.creosotemaps.com/blm2020/). These protests are a reflection of both the international solidarity with the US BLM movement and the antiblack racism that persists across the world.

Although the causes of the crises are different, COVID19 and the protests share two things that merit immediate deeper reflection, especially among socio-ecological practitioners, theorists, and researchers. First, both disproportionately affect Black, Indigenous, and people of color (BIPOC) ${ }^{1}$ groups that have been systematically oppressed, subjected to racism, and excluded from economic opportunity and political representation. Second, both have had very dramatic manifestations in public spaces, especially in parks and streets.

Increased exposure, higher levels of underlying health issues, and lack of healthcare, combined with a limited availability of testing are the common reasons cited for the disproportionate toll of COVID on BIPOC communities (CDC 2020). BIPOC individuals are more likely to hold jobs deemed "essential" (e.g., parcel delivery, hospital or grocery store staff, and food processing workers), and unlike white collar employees who could transition to remote work, essential workers continue to risk exposure to potential infection. Simultaneously, the sudden decrease in service sector work due to business closures resulted in disproportionate increases in unemployment among BIPOC

\footnotetext{
1 Note: Throughout this piece, we will use the acronym BIPOC broadly to refer to non-white people. We embrace this term over "People of Color" because it intentionally acknowledges that Black and Indigenous people have borne the worst consequences of white supremacy. For more information and perspectives on the meanings, acceptance, and context of the acronym BIPOC, we refer the reader to (Garcia 2020). Where we discuss issues that pertain specifically to the Black community, we will use the term Black.
}

individuals in a world where Black and Indigenous communities already have the highest rates of unemployment in the country (Kearney and Pardue 2020).

The built environment has also played a role in establishing and maintaining systemic reasons for these pandemicrelated outcomes. Those that have examined the role of the built environment tend to focus on correlations between COVID-19 mortality and density. More focus is needed on how race and gender interact ${ }^{2}$ with health and social processes of planning to create and maintain unjust and unseen systems and racialized experiences in the built environment. This includes urban parks and public open spaces whose significance during the pandemic has increased. As Lipsitz wrote on race-specific spatial imaginaries in urban landscapes: "the lived experience of race has a spatial dimension, and the lived experience of space has a racial dimension" (2007, p 12).

Simultaneous to the COVID crisis, demonstrations against antiblack violence show how racial minorities bear the disproportionate brunt of the consequences during racial unrest. Black businesses are disproportionately destroyed, Black protesters are more likely to be arrested and treated with excessive force, and Black communities are left with the burden of fighting to correct centuries of systemic oppression and the trauma of violence, apathy, and tokenism. It is wise to remember however, that "the cries of Black Power and riots are not the cause of white resistance, they are consequences of it (King 1967, p 12). These realities are visibly and starkly represented in our parks and public spaces. As social-ecological researchers who engage with these spaces often, it is imperative that we give primacy to examining these relationships in our scholarship and works.

This piece is admittedly centered on the US experience of both COVID and race. However, for our international colleagues and readers of this journal, we hope our perspective and suggestions for how best to proceed out of this time of crisis illustrate broader themes, such as: (1) the necessity of considering all forms of environmental justice (such as procedural and activism), in addition to distributive justice in socio-ecological practice ${ }^{3}$ and research; (2) the importance

\footnotetext{
2 Kimberle Crenshaw's coining of the term intersectionality, where she describes the unique ways hidden systems of oppression express themselves in place, location, and environment along lines of gender and race. See Crenshaw. 1999. Mapping the Margins: Intersectionality, Identity Politics, and Violence against Women of Color. Stanford Law Review 43 (6), 1241-1299.

3 "Socio-ecological practice by definition is the human action and social process that take place in specific socio-ecological context to bring about a secure, harmonious, and sustainable socio-ecological condition serving human beings' need for survival, development, and flourishing. It includes six distinct yet intertwining classes of human action and social process-planning, design, construction, restoration, conservation, and management (Xiang 2019, p 7; 2020)."
} 
of recognizing both historical determinants of inequities in the built environment and how social processes tend to reproduce power configurations in the present; and (3) how singular focuses on normative socio-ecological goals in a time of crisis can inadvertently reproduce unjust power structures. We draw on a vast body of literature from fields across the humanities, social sciences, physical sciences and urban planning to inform and guide our understanding on these processes.

\section{Space as oppression and liberation: events, words, and images}

This section presents a series of vignettes using images from the media during this time of dual-crisis in the US. We use juxtaposed images to capture the relevance and emotion of the present moment, and reflect on the manifestation of oppression and liberation embedded in the built environment. The images show how central public open space is during this time (Mell, 2020; Douglas et al. 2020, p 18), while also revealing the cruelty of racial and economic disparities in our cities, and how the physical environment is used explicitly and implicitly to configure social power relationships.

\subsection{Vignette one: parks as refuge}

Early in the US pandemic, a photograph of temporary field hospitals to manage the surge of COVID-19 patients in Central Park, New York City, NY (US east coast) stood out (Fig. 1, top). The park, conceived of by Frederick Law Olmsted in 1858 as the "lungs of the city," (Fisher 2010), was envisioned as a socio-ecological shock absorber for the harsh realities of urban life during the Industrial Revolution. As the lungs of the city, the park could serve the functions of alleviating poor "miasmas" thought to be the cause of many public health issues at the time, while providing natural functions, such as absorbing stormwater runoff, and improving mental health (Eisenman 2013, p 290). Thus, when the park served as additional emergency treatment space for 315 COVID-19 patients, a disease which has killed over 20,000 New Yorkers (Linton 2020), it was quite literally absorbing a public health shock. As requirements for physical distancing have increased, the roles that parks play as sites of recreation, distanced socialization, access to nature, and exercise have also become more pronounced, leading to more recognition of the essential services that parks provide, especially in times of crisis (Bronin 2020).

Yet, the contrast of another image caused us to reflect on access to these multifunctional urban parks during times of crisis. The second image (Fig. 1, bottom) shows temporary "housing" being provided in the empty parking lot of a sports arena, with white rectangular boxes painted on the asphalt to indicate the physical distance people were advised to keep while sleeping in the open air (Jeffery 2020). This example, from Las Vegas, Nevada (western US), illustrates how the most marginalized, in this case, people experiencing homelessness during a pandemic, may, in reality be pushed further from the spaces that can more comfortably accommodate shock, rather than be embraced into them. While not surprising, without widening our lens, it may not be readily apparent who is excluded and included in the adaptive use of public open spaces. While park space has exhibited its flexibility and multifunctionality during the pandemic, questions of fairness, justice, and compassion in the spaces themselves can be easily overlooked.

\subsection{Vignette two: racialized surveillance in parks}

Approximately one month later, we began to see photos of circles painted on park lawns with the goal of also encouraging physical distancing while enabling people to enjoy the outdoors as the weather improved (Fig. 2, top). The increased relevance of outdoor open space during the pandemic has certainly brought attention to parks and urban nature as critical and safe amenities for urban residents (Douglas et al. 2020). While the painted circles were intended to support safe use of parks, we were left thinking how the enforcement of physical distancing regulations in public spaces are experienced differently across racial groups. Indeed, in New York City, it was later reported that the majority of distancing violation citations issued by police were to Black residents (Southall 2020). While to some, the circles represented the recognition of the importance of parks, for others it is another example of how power and racism are reproduced in public spaces through the surveillance of space, with public health as a pretense (see Carr 2014).

The racialization of space occurs not only directly through policing of the enjoyment of space, but through the intentional wielding of surveillance by white civilians and institutions on Black and brown park users. On May 25, 2020, Christian Cooper, a Black man birding in Central Park was falsely reported to the police by Amy Cooper, a white woman, after he confronted her about her (unlawfully) unleashed dog. Her threat to "tell [the police] there's an African American man threatening my life," captured by Mr. Cooper on video, demonstrates the rapid ease in which Ms. Cooper weaponized racism as a tool for her advantage and to assert her power in the public space. Knowing very well how the police would respond to a Black man threatening a white woman, Ms. Cooper intentionally placed not just Mr. Cooper's life in danger, but every Black man in the immediate vicinity. For many, the racialized use of power against Mr. Cooper was reminiscent of Carolyn Donham's false accusations that led to the murder of Emmett Till. For 
Fig. 1 Top: the Samaritan's Purse Emergency Field Hospital in Central Park, May 8, 2020. Source: Lucas Jackson/Reuters; used with permission. Bottom: Las Vegas parking lot re-purposed for a physically distanced homeless "shelter," March 30, 2020. Source: Steve Marcus/ Reuters; used with permission
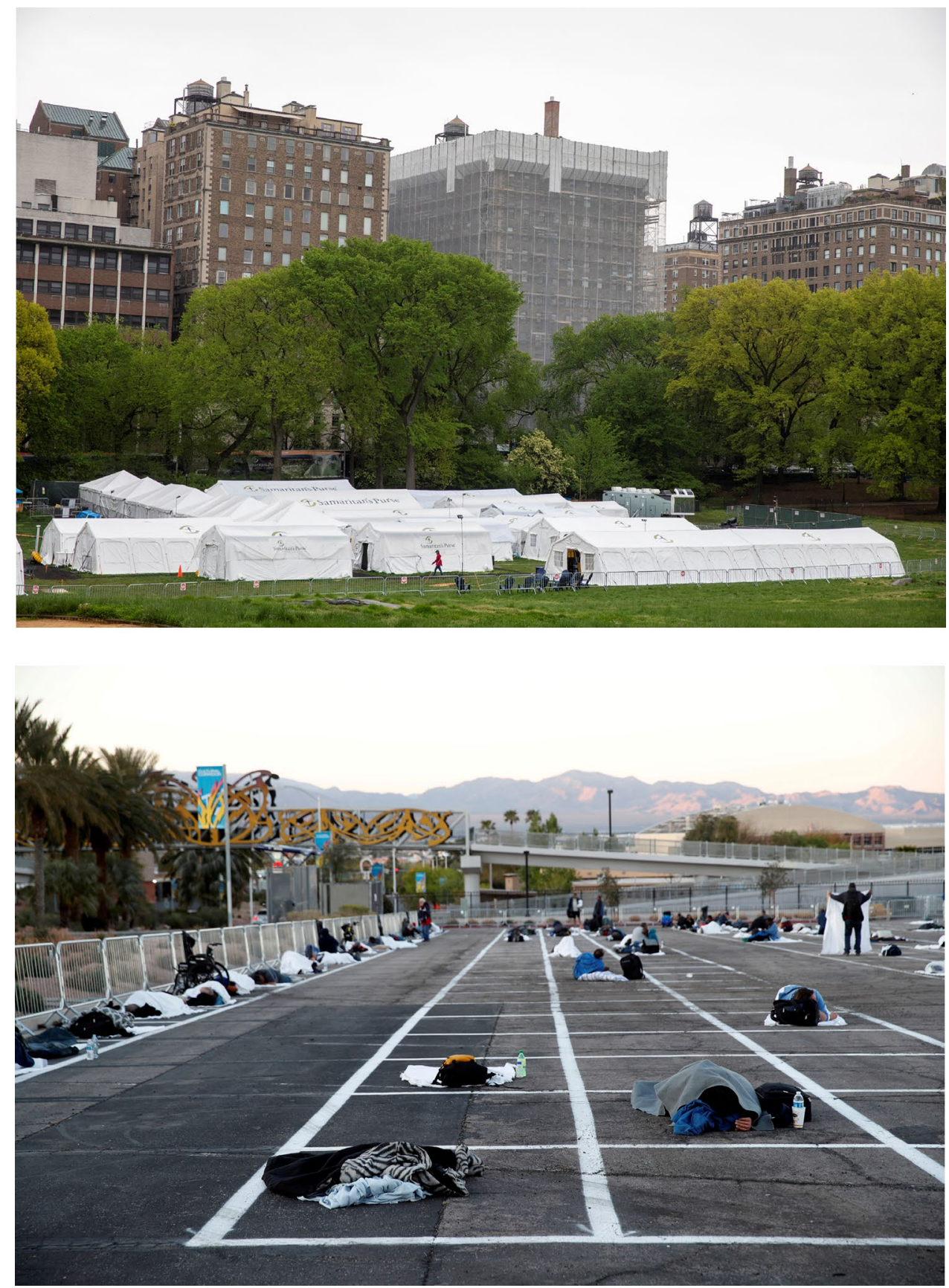

many white and non-Black Americans, this was a stunning example of how overt racism is wielded against Black people in all public spaces.

In response to this reality, MacArthur Genius and Carnegie Hall performer Walter Kitandu created a satirical Public Service Announcement (Fig. 2, bottom) that captures how surveillance by white residents and police racializes space and innocent outdoor activity. He says:

“... as a black person, as a person of color in this country, every time you walk out the door, there's always [this] calculus running in the background about how to present, how to keep yourself safe. It's a muscle that's well exercised by people of color in this country. I can't really think of anything more wholesome than standing under a tree and watching a hummingbird build her nest, but I think if our activities fall outside of the framework of possibility that's established for us by the white imagination, then we're at risk" (Bittel 2020). 
Fig. 2 Top: a New York Police Department officer enforcing social distancing regulations in Brooklyn, NY. Source: Eduardo Munoz/Reuters; used with permission. Bottom: a satirical Public Service Announcement made by and of Walter Kitandu, a Black man that reads "Advisory! Have you seen this man?" ending with "Save your fear for something that counts." to educate white people on the non-threatening presence of Black people birdwatching. Source: Walter Kitandu; used with permission
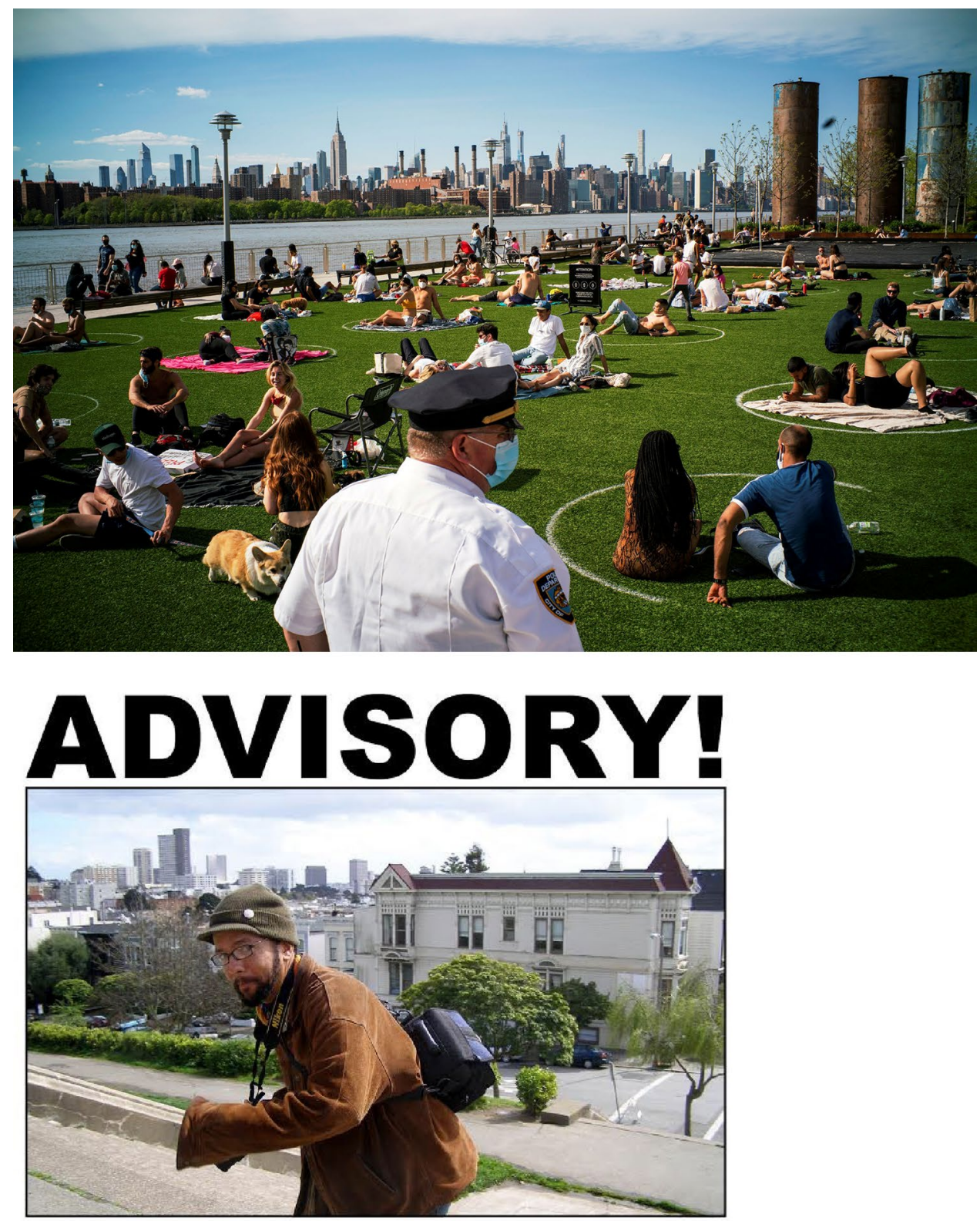

HAVE YOU SEEN THIS MAN?

$\mathrm{He}$ is a black man and also a bird photographer. While this combination may be rare rest assured it is generally not considered DANGEROUS. Having these characteristics does not automatically qualify him as "SUSPICIOUS." Granted, he does often stand still for long periods, near bushes, and exhibit short bursts of speed in pursuit of a good image. Be aware that, overall, he finds the birds in the park much more interesting than the people striding through it - and his camera is not trained on you. He will not harm your dogs, children, sisters, mothers, brothers, or friends. He may even offer you help when needed, or a smile, a chance to see a close up of a hawk or hummingbird. Do not CALL THE POLICE unless you see him being accosted by another party. Do not FLAG DOWN A PATROL CAR. Save your FEAR for something that counts. And have a lovely day.

Below are actu

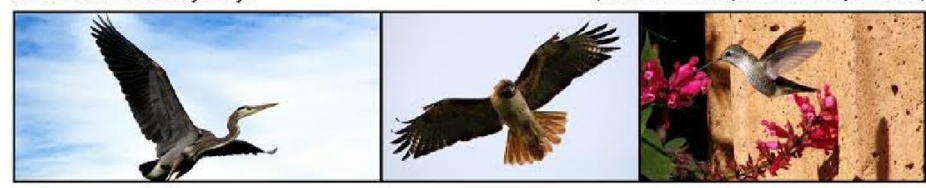


Though many urban parks are designed to be multifunctional and flexible socio-ecological spaces, this flexibility and multifunctionality also means the space can be used to reproduce injustice through how comfort is allocated, the efforts made by police to maintain racial hierarchies ${ }^{4,5}$ or the maintenance of power of whites over people of color.

\subsection{Vignette three: civil rights in the right-of-way}

Public spaces and the right-of-way provide another important look into the interactions between race, open spaces, and injustice. Streets, sidewalks, roads, and highways are all common sites for urban greening projects, often rationalized by normative goals such as increasing urban walkability, and making cities more livable. Therefore, when COVID-19 provided an opportunity to prioritize people's use of streets over vehicle traffic through the enactment of street closures, it was not surprising to see many urbanists praising cities closing roads to cars to provide more access to open space and open-air dining for urban residents (Fig. 3, top). Juxtaposed to this image however, is another image of people occupying the right-of-way (Fig. 3, bottom) for a BLM protest that shut down a highway.

This vignette illustrates how urban public space is a product of racialized processes of the past, the ongoing racialization of space as well as the spatialization of race as discussed in Lipsitz (2007). The contrast between images of residents on urban street closures (often white, on treelined streets, physically distanced), and the BLM protesters (mostly Black, crowded, and on the highways), illustrates how and for whom amenity is granted, versus how and by whom justice is demanded, and how these are and have been spatially situated within our cities around race. The setting of the highways themselves are a reminder of how embedded racism is in our physical environments. In many cities, the highways blocked by protesters are the same highways that bisected vibrant BIPOC neighborhoods, displacing residents, disrupting community cohesion and strangling them from economic growth during the period of "urban renewal" in the 1940-70s (e.g., Poon 2020; DiMento and Ellis 2012).

This vignette also illustrates the damage in trust that occurs when capitalist outcomes are prioritized over equity

\footnotetext{
4 We define racial hierarchies as a system of one group believing they are superior to others. In the context of global institutional racism, whites and proximity to whiteness are considered superior, resulting in an alignment of power, privilege and resources for white or Eurocentric features, values and myths.

5 In LA, California (US west coast), trees are often heavily pruned or cut down in favor of police camera towers, and low growing shrubs are used to prioritize highly-lit open spaces for tracking or surveillance in downtown LA and other majority BIPOC communities. See 'Shade' in https://placesjournal.org/article/shade-an-urban-desig n-mandate/?cn-reloaded $=1$.
}

or long-term concerns. For example, in response to the "pop up" urbanism of spontaneous street closures for outdoor restaurant seating, planner and anthropologist Destiny Thomas warns: "That knee-jerk reaction exposes the power structure, the decision-making autonomy, and the centering of certain people's comfort and freedoms over others" (Badger 2020; Thomas 2020).

The juxtaposition of the two images illustrates how the process of racializing space continues to be reproduced. As BLM voices are silenced, they are increasingly forced to seek spaces that are more disruptive yet more dangerous to the status quo. The results of which have led to intentional and attempted murders of protestors in the streets by police and civilians alike (such as in Kenosha, Wisconsin; Charlotte, North Carolina; and Portland, Oregon). While the closure of urban streets illustrates the process of how policy-makers and planners work for the people, protesters must occupy dangerous spaces in order to demand equity and justice.

\subsection{Chaos or Community?}

The above vignettes illustrate how both crises manifest in urban public parks, streets, and open space, and both crises reveal a stark truth about American society: that racial inequality, and in particular antiblack racism, is not "history." Not only is antiblack racism present, it continues to be reproduced through policies, institutions, and individuals. As stated in the introduction, because COVID-19 essential workers are more likely to be Black or brown individuals, the dual crises of COVID-19 and the murders of George Floyd and others by police show again how much society depends on, yet devalues Black life. While more people are paying attention to systemic racism and inequities in our systems, will this result in substantive change?

As Erin Aubrey Kaplan wrote recently in the New York Times:

"Recognizing that Black people matter as much as all other Americans is only acknowledging what's always been true. Embracing Blackness as something of value and dignity is a baseline for progress, not progress; it is moving into position at the starting line, but it is not the race."

The solution to antiblack racism must move beyond intellectual acknowledgement. Real change in actions is required, and the burden is on non-Black people to "catchup" on the American racism that Black people have always known. To quote Kaplan again, racial privilege is "the phenomenon of not having to think about the costs of oppression, or about Black people at all. Antiracism requires the opposite: engagement" (Kaplan 2020). In other words, we must move beyond emphasis on describing distributional 
Fig. 3 Top: a closed street in Manhattan, New York City to help support physical distancing during COVID-19, May 2, 2020. Source: Eduardo Munoz/ Reuters; used with permission. Bottom: people sit on Highway 395 in Washington, DC during a demonstration against racial inequality, June 14, 2020.

Source: Erin Scott/Reuters; used with permission
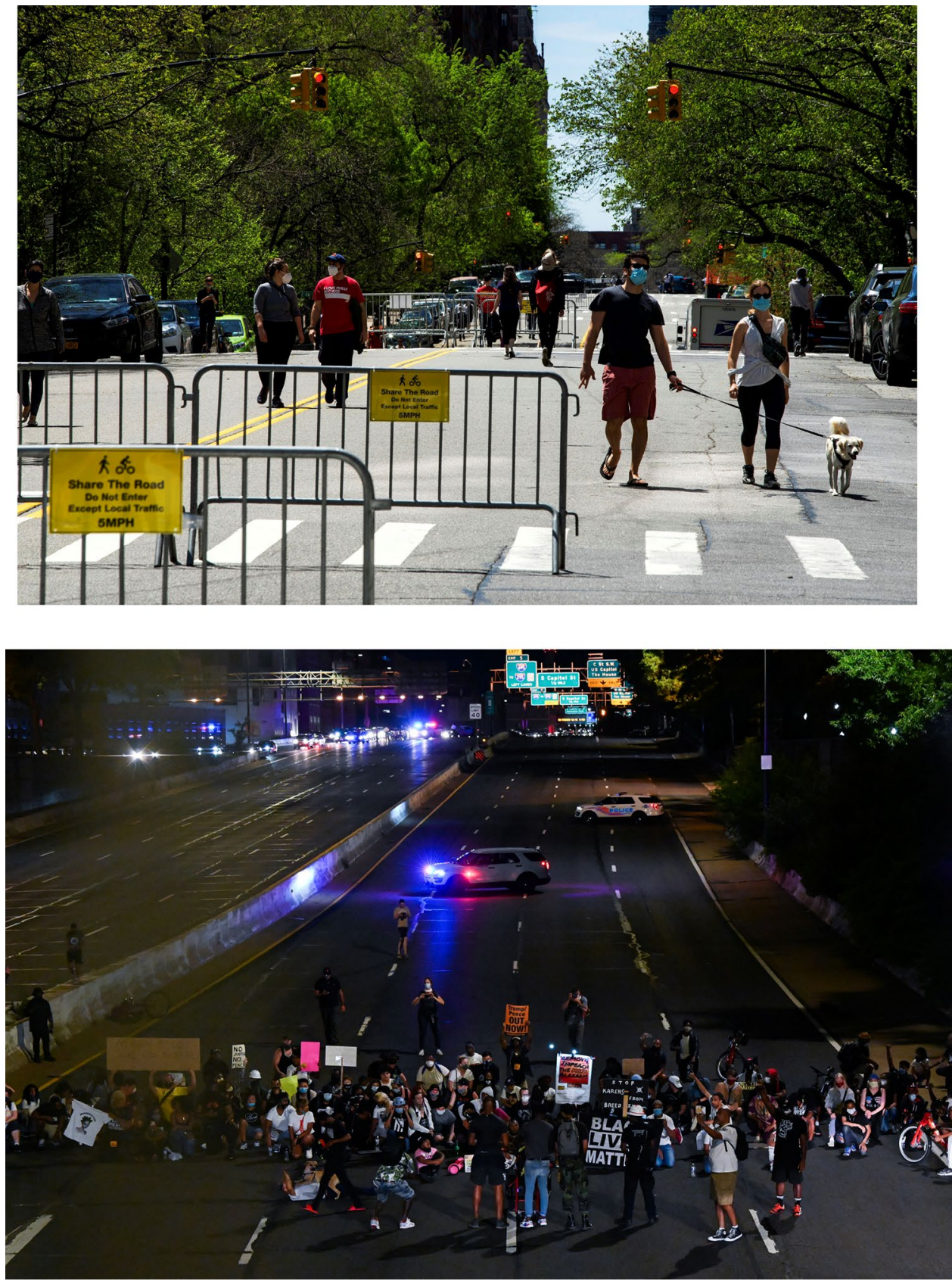

inequity, towards the process of meaningful participation and redistribution.

"Where do we go from here?" is the question posed by Rev. Dr. Martin Luther King Jr. in the title of his last book before his assassination in 1968. In his book, King reflects on the current state of race relations after the passing of the civil rights legislation, and aptly points to the continued white apathy and disinterest of whites re-educating themselves out of their racial ignorance, a driving barrier to racial and social justice (King 1967, p 9). Almost prophetically, King details a crossroads where the potential for community lies in political, economic, and ideological system changes. Building community and anti-racist systems thus will require a deconstruction of these institutions, creating new systems and sacrifice. Our alternative otherwise is chaos. The following sections outline ways practitioners and researchers can integrate anti-racism framings into their work through two avenues. First, a stepwise approach with differentiated entry points to help increase racial consciousness in socio-ecological practice and research, and move from a distributional focus of justice to a more procedural one. We provide an example using urban parks to illustrate this approach. Second, efforts to improve and expand past procedural justice are organized into concrete actions that 


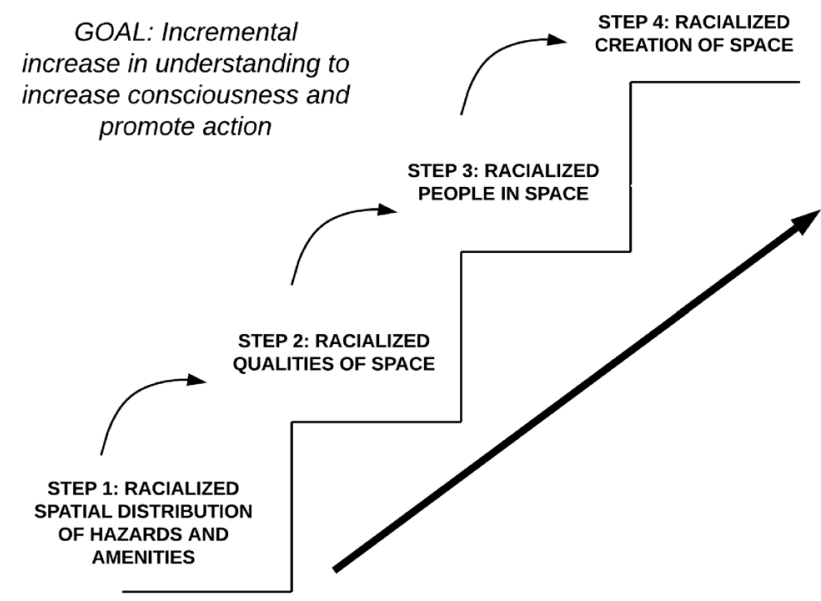

Fig. 4 Conceptualization of a stepwise approach to closing the "gaps" in antiblack racial consciousness for socio-ecological practitioners and scholars. The goal is to promote incremental increases in understanding to increase consciousness and promote action. Step 1: racialized spatial distribution of hazards and amenities, Step 2: racialized qualities of space, Step 3: racialized people in space, Step 4: racialized creation of space

can be incorporated into the work of socio-ecological practitioners and scholars.

\section{Stepwise approach to increasing antiracist consciousness in socio-ecological systems, planning and research}

The intention of a stepwise approach is twofold: to provide readers with various entry points that increase their awareness of the role antiblack racism has played and continues to play in socio-ecological systems, and to encourage more critical thinking about the direct relationship between antiblack racism and the reader's scholarship and practice. "Recognition" is the theme of Nancy Fraser's post-distributive framing of justice (Fraser 1995). The goal is to see how justice is practiced and embedded in cities. The stepwise organization can be applied to any subject matter; here urban parks and greenspace are used as an example (Fig. 4).

\subsection{Step 1. Racialized Spatial Distribution of Hazards: Where are the parks?}

Traditional measurements of equity in parks planning are based on the conventional distributional understanding of environmental justice. Decades of research in environmental justice shows that globally, environmental inequities, such as exposure to sources of pollution, are much more likely to be experienced by Black and brown neighborhoods compared to white neighborhoods (e.g., Bullard 1997; Schlosberg 2007; Holifield 2013; Agyeman and Evans 2004). Over time this work has expanded to include how BIPOC communities are also located further from environmental amenities, such as parks. As parks are associated with increased physical exercise and mental health outcomes (e.g., Kuo 2001, pp 20-23), a lack of access or amenities based on race becomes an environmental justice concern (Sister, Wolch, and Wilson 2010, p 236). Green spaces in urban areas may also reduce the effects of urban heat island temperatures and air pollution, and parks provide an important social infrastructure that promote and allow for important community placemaking and building (Chiesura 2004, p 339; Gobster and Westphal 1998, pp 186-188). Some studies have shown that well-maintained green space is associated with improved public safety (Branas et al. 2011, p 6; Kondo et al. 2015 pp 118-119).

Recognizing the benefits that parks can provide to urban residents, several important metrics have emerged to quantify the spatial distribution of parks in cities. These include average resident Euclidean distance to parks, quantification of park "catchment areas," and average walking or driving times to parks (Landry and Chakraborty 2009 p. 2657; Boone et al. 2009, p 771; Heynen, Perkins, and Roy 2006, pp 7-8). A common unit of observation used to study parks' spatial distributions within cities is census tracts or census blocks. These geographies enable relatively convenient associations to be made between socio-demographic variables and park areas. Park area is negatively correlated with the proportion of BIPOC residents in the tract. For a practitioner or scholar whose entry point is Step 1, the answer to the problem of spatial distribution may seem relatively straightforward: more park areas are needed in BIPOC neighborhoods.

\subsection{Step 2. Racialized Qualities of Space: What is in the Parks? What's Around Them?}

Arriving at Step 2, we recognize the spatial inequities in the distribution of SES, and bring a critical eye to the inequities within the spaces themselves. Parks differ in design and experiential quality, including: the facilities, landscaping, and size (Byrne and Wolch 2009, pp 745-748). Therefore, while studies have shown that exposure to nature in urban settings has positive effects on behavior, social ties, and mental and physical health, different parks yield different levels of support for biodiversity and active exercise (Kuo 2001, pp 20-23; Ulrich 1986, p 21; De Vries et al. 2003, p. 1721; Sadler et al. 2010; White et al. 2013, p 925; Maas et al. 2006, p 591). In the US, larger parks that can support urban forests, jogging or biking are more likely to be located in wealthier, whiter areas of the city (e.g., the Monon trail in Indianapolis, Indiana; Central Park in New York City, New York; Forest Park in St. Louis, Missouri). In contrast, parks in poorer, Black majority neighborhoods, may be co-located 


\section{If you take a car" the park is too far!}

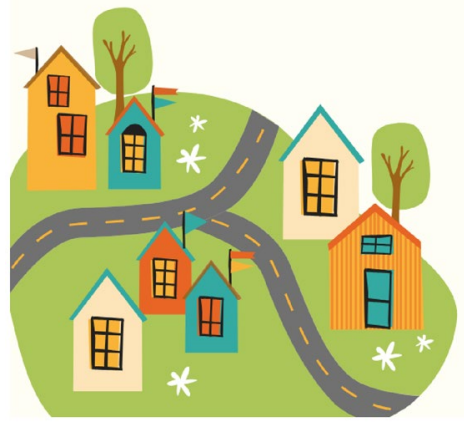

Fig. 5 A public information campaign graphic instructing residents to "recreate responsibly" by only using parks to which they can walk or bike during the pandemic in Mercer Island, Washington. Source: Government of Mercer Island, Washington; Used with permission

near hazardous sites, may previously have been the sites of severe pollution (Su et al. 2011, p 323), or lack upgraded amenities (Sister, Wolch, and Wilson 2010, p 244).

Parks in predominantly Black and Latinx neighborhoods are also more likely to suffer from "park congestion." A study of park use, need and facilities in Los Angeles, California found that lower-income neighborhoods were more likely to have higher user density than higher-income neighborhoods (Sister, Wolch, and Wilson 2010, p 240). In another example, Kansas City parks in low income communities were more likely to contain basketball courts, less likely to have trails, and less likely to have aesthetic features (Vaughan et al. 2013, p 13). These inequities are exacerbated during a pandemic particularly as parks perceived to have higher user density or high contact activities such as basketball are more likely to be closed, and physical distancing is enforced by police.

As a result, Black and brown park goers find themselves left with few options close to home, and are further inhibited by public service announcements to stay close to home and city park actions such as closed parking lots (Fig. 5) (Gobster 2002, p 153).

Practitioners and scholars whose entry point is Step 2 acknowledge the race-based inequities of space beyond the unequal spatial distribution of parks to include the unequal quality of spaces, functions of space, and the spatial contexts of urban greening, and the dynamic nature of space: how people react to the space, and how they create it. Practitioners and scholars at this level should understand the importance of participation and representation in the planning process when deciding community priorities, and possess a broader view of the inter- and intra-actions between race and planning.

\subsection{Step 3. Racialized People in Space: Who Gets to Be in Parks?}

Step 3 necessitates understanding the interactions between place, people and the systems of racial oppression, historical and current, that uphold and sanction individual acts of racism. Here, we recognize that not only is racism internalized in every individual, but embedded in the way people are viewed in space and place. Step 3 acknowledges how racism is experienced by and imposed on BIPOC park goers.

After Mr. Cooper's Central Park incident video was viewed over 40 million times, a Twitter hashtag \#blackbirdersweek, \#BlackAFinSTEM, and weeklong event series was started by a collective of Black scientists and birders. ${ }^{6}$ In a video posted to Twitter, one of the organizers said:

"For far too long, Black people in the United States have been shown that outdoor exploration activities are not for us, whether it be because the way the media chooses to present who is the 'outdoorsy type' or the racism experienced by black people when we do explore the outdoors, as we saw recently in Central Park.[...] Help us to show the world, especially the next generation of young black birders and nature enthusiasts, that we exist, that they are welcome, and that this space belongs to them too."

Black naturalists shared their experiences of having the police called on them simply for enjoying nature, because these activities were outside of what whites could imagine Black people doing (Bittel 2020). Racism and the threat of being misinterpreted by white people and police prevents Black students, professors, scientists, and everyday people from being able to enjoy nature without the constant threat to their safety and wellbeing (Roberts and Zamore 2020).

The reality of our public green and open spaces is that Black and brown people are more heavily policed and surveilled, leading to arrests, citations, and in some cases, death. In NYC, (as of May 7, 2020), 35 out of 40 police arrests for COVID-related physical distancing violations were Black (Southall 2020). The pandemic reminds us as SES practitioners and researchers, that in addition to being different in design and distribution, BIPOC individuals' access to any potential benefits of a public green space is dictated by authorities' decisions (read: white supremacy) about how that space can be used and accessed.

If in our lens as socio-ecological practitioners and researchers, we claim parks as the shock absorbers of a

\footnotetext{
6 Hashtag creators included: Anna Gifty, Chelsea Connor, Danielle, Sheridan Alford, Tykee James, JD Monroe, Event Organizers: Corina Newsome, Tyler Jones, Cassandra Ford, Earyn McGee, and Juita Martinez.
} 
pandemic because they provide people with places to recreate and relax, and can be used to respond flexibly during times of crisis, then we must also use our lens to recognize that these spaces are not neutral, and are unlikely to provide ecosystem services to all. Practitioners and scholars whose entrypoint is Step 3 acknowledge that the physical qualities, contexts, and facilities of parks do not reflect the full extent of the racialized experience of parks. If we are to call ourselves socio-ecologists, then racist social interactions in physical spaces must be considered within our purview.

\subsection{Step 4. Racialized Creation of Space: Why and How are Parks Created?}

In explaining the current state of why urban parks are distributed the way they are and why patterns of inequality and racism continue to reproduce themselves through these spaces, we must recognize that the production of both urban space and nature are social processes. Sociologist Henri Lefebvre referred to this as the "social production of space." With respect to "nature," theologian and author CS Lewis said, "What we call Man's power over Nature turns out to be a power exercised by some men over other men with Nature as its instrument."

Nature as an instrument for the creation of exclusionary spaces is also tightly woven with health in both language and planning design. For example, Sara Jensen Carr examines the narratives between the built environment and illness. In particular, she highlights examples of urban renewal programs, the removal of Black residents and their association with blight, and the way urban renewal served as a tool to exclude and remove Black residents from urban spaces (Carr 2014). Post-Jim Crow and the civil rights passage, the codification of racist exclusionary practices were incorporated into building codes, zoning, covenants, redlining and planned, gated communities, under the guise of beautification, health or risk management (Carr 2014, p 5; Heathcott 2005, p 329; Glotzer 2020). The legacy of redlining continues to reinforce racial segregation, deny educational and employment opportunities, and create lower quality public spaces compared to formally higher rated neighborhoods (Locke et al. 2020).

Racialized production of urban spaces includes parks and open space, through which city policies may reinforce environmental racism. Historically, exclusion and spatial segregation through parks planning has been an explicit goal (Rigolon and Németh 2018, p 8). In Boston, Massachusetts, parks have been shown to function as "boundary landscapes" separating neighborhoods of different demographics (Solecki and Welch 1995, pp 98-99). In Chicago, Illinois, specific park amenities such as public swimming pools in the South Side were intentionally planned in Black neighborhoods to discourage Black residents from using similar amenities in white neighborhoods (McCammack 2019). In today's post-industrial cities, vacant parcels in majorityBlack neighborhoods are contested lands over which both city departments and individuals exhibit paternalistic or colonialist attitudes that may prioritize some definitions of health over others. For example, in North St Louis, Missouri, a white couple repurposed two vacant residential parcels in the predominantly Black neighborhood for an urban composting business and chicken farm. The noxious odors of the chickens and compost produced now prevent neighborhood children from playing outside. When confronted with the complaints, the couple stated they planned to "teach" neighborhood residents how to grow healthy food, while working on a "solution" to the high rate of vacant lots in North St Louis (Toomey 2020).

The perception of the link between urban greening and white displacement of longtime Black residents is so direct and clear that some Black residents have come to view greening itself as a LULU (locally unwanted land use), an acronym that began as a descriptor of the hazardous facilities that bore the environmental justice movement in the first place (Anguelovski 2016, pp 27-29; Immergluck and Balan 2018, pp 559-560). Neighborhood gentrification is also a process of criminalization, in which calls to police and surveillance of BIPOC individuals increase as white residents move in and proceed to re-orient, or doubly racialize the space to suit their needs (Butler 2017; Fayyad 2017). There is increasing evidence that gentrification is linked to changes in policing patterns that disproportionately harm BIPOC individuals, and intersecting trans residents and communities. The link between gentrification and increased policing has been documented both qualitatively (e.g., Maharawal 2017; Lyons et al. 2017) and quantitatively (e.g., Beck 2020). The relationships between displacement, space, and illness in Black communities is well documented in biosocial psychology: the "root shock" of placelessness and the betrayal of trust in the government to protect all citizens causes direct and indirect harm to Black peoples' physical health, mental health, and community health (Fullilove 2001).

In Step 4, scholars and practitioners should be aware of the potential for nature, green and open spaces to act as spatial codifications of social power and whiteness. Practice, research and design at this stage should include an integration of activism and scholarship rooted in cross-disciplinary studies such as Black geographies, critical race theory, and environmental justice. These fields focus on the effects of racialized power, its spatialized production and manifestations (e.g., Brand and Miller 2020; Lipsitz 2007; Pellow 2016; Bates et al. 2018), as well as hierarchies of both race and gender in environmentalism (Frazier 2019; Taylor 2002), and present new ways of imagining, valuing and recognizing space, place-making, and resilience created within Black communities with and in absence of whiteness, and as 
it relates to nature (Allen et al. 2018; McKittrick and Woods 2007; Frazier 2016, 2018). In particular, we see this step leading into an understanding and valuing of place-making and sense of place (both theory and practice). Recognition of these values would shift focus from the physicality of location, to experiences and interactions that shape people's relationship to place.

\section{Action principles for environmental, parks, and open space advocacy and scholarship}

Finally, using the Stepwise Approach, we posit four principles for planning and studying parks and open spaces that practitioners and scholars can incorporate into their work.

\subsection{Prioritize the voices and experiences of BIPOC residents}

Black narratives that express how parks are not neutral spaces must be believed, acknowledged, and elevated. NonBlack SES practitioners and researchers should go beyond the "desktop analyses" of measuring proximities, areas, and correlating them to census-based geographies. We need an understanding of the qualities of space that make it contentious, as well as the elevation of planning priorities identified by BIPOC communities. We need to plan with communities to create examples of parks that actually serve BIPOC communities. Given the complexities of how racialized space is produced and experienced, doing this well will require scholars and practitioners to actively seek out missing voices and listen.

Recently, Brand and Miller developed a bibliography for urban planning researchers and practitioners that includes works that unpack the racialized spatial imaginaries that are relevant to SES practice and research. Unfortunately, while urban planning education does typically include topics on environmental justice and equity planning, deeper exploration into critical race theory and Black geographies scholarship has not been incorporated into planning curricula (Brand and Miller 2020, p 6). It is increasingly clear that sources, such as those from Brand and Miller's bibliography need to be incorporated into more planning curricula to ensure the next generation of planners understands the relationship between racism and the built environment (Edwards and Bates 2011; Greenlee et al. 2018).

Ian McHarg, widely recognized as one of the founders of socio-ecological planning and design, developed the land suitability assessment method of identifying areas suitable for various social and ecological goals (McHarg
1969; Steiner and Fleming 2019). Today the process of gathering spatial data layers and assigning them weights according to suitability for socio-ecological uses to create composite maps is used in participatory geospatial modeling to engage stakeholders. Participatory geospatial modeling is intended to aid multidirectional learning and co-production of knowledge between experts and residents and across disciplines (Rodela et al. 2017). Because McHarg's work did not engage race, the stepwise approach we propose and its relationship to space would be a useful contextual tool to incorporate as another key layer of space through which the landscape can be understood.

\subsection{Prioritize inclusion efforts over opportunism and narrow urbanist agendas in practice and research}

Given that parks and greening can result in housing insecurity, increased policing, and mental and physical harm in BIPOC communities, we need to think creatively about how to avoid these problems (Wolch, Byrne, and Newell 2014; Fullilove 2020; Shi 2020) and new processes. For researchers, we need to avoid siloed conceptualizations of ecosystem service provision. Practitioners might consider facilitating innovative partnerships between governmental agencies to ensure environmental planning, housing, and other neighborhood services (especially as alternatives to policing) are simultaneously considered.

Parks and open space planning is a political process much more than it is a technocratic or scientific one and therefore the key issue is elevating the needs and wants of the residents themselves. This consciousness is especially important because of the historical dominance of the perspectives and values of groups in power in creating space (Dwyer and Jones 2000, pp 209-211). Although COVID19 is showing us how important parks are, it is critical to remember that the population that is suffering from higher infection/death rates and higher rates of unemployment, are likely to face significant barriers to participating in planning processes during or directly following the COVID disaster. Research from other disasters shows that people need time to recover from both economic shocks and psychological and emotional grief (McKittrick 2011). Changes to the built environment need to both prioritize these voices and acknowledge limitations of participants' time and resources during crises. This means that antiracist planning and opportunistic planning may often be at odds and that a singular focus on socio-ecological outcomes in the period of recovery following disaster can discount the very voices they purport to be helping. 


\subsection{Use or expand inclusionary participatory practices in practice and research}

Often "participation" of disenfranchised communities or individuals only goes so far as to allow steering committees to rhetorically promote diversity or inclusion. As Dr. King stated, "the ability to be independent, assertive and respected when final decisions are made is indispensable for an authentic expression of power" (King 1967, p 148). Participation includes empowering and valuing the voices of disenfranchised residents, recognizing the voices not present, and re-orienting the formulas of evaluation. Culturally rooted, authentic inclusions are spaces of power that allow people to construct place meaning (Scannell and Gifford 2010, p 3). For example, substantive efforts need to be made to ensure that if and when individuals from these communities attend participatory planning sessions and public meetings, their views are taken seriously, the conditions created that prevent full or partial participation are acknowledged or rectified, and the views being expressed are able to do so without fear of being minimized or dehumanized. But, even better than this would be the expansion of participation towards more substantive inclusion through supporting leaders in oppressed communities in both practice and research (Roberts 2020).

Researchers can reference sense of place theory and Black geographies as sources for process, while practitioners can look to the organizations, individuals and communities these theories often highlight. An example from practice is the Sustainable South Bronx organization (SSBx), a nonprofit organization that advocates for green and open space development in the South Bronx, a predominately Black and brown borough of New York City, that has historically and still bears much the New York's environmental hazards, and with the lowest parks to people ratio for the city. They offer three programs: SSBx, a 12-week green job training program that couples with community based projects such as stream restoration, water quality testing, and tree surveys. NYC CoolRoofs, where they hire individuals to paint reflective coating on roof tops as transitional paid jobs, and Intervine, a training and employment program for creating and maintaining green infrastructure (https://www.ssbx.org/). Founded by Majora Carter in 2001, her efforts to "Green the Ghetto" brought the first waterfront park to the Bronx in over 60 years. A Black woman born and raised in the Bronx, her organization goes beyond just participation but challenges the city of New York and planners to rethink economic systems connected to the built environment and center Environmental Justice (EJ) communities. ${ }^{7}$ In a TEDxMidwest

\footnotetext{
7 Environmental justice communities refers to communities of color, low-income, tribal or Indigenous communities that experience disproportionate and negative effects of environmental hazards and decisions.
}

talk on the value of local eco-entrepreneurship, Ms. Carter emphasizes that "[w]e are the key to our own recovery." Her work and the work of those she highlights are driven by their relationship to their communities and desire for healthier environments. For white practitioners and researchers in particular, inclusionary practices will sometimes mean taking a step back, sacrificing a leadership role, and empowering members of EJ or disenfranchised communities to lead the way and determine the direction. This example extends beyond the conventional understandings of participation, in which marginalized voices are "brought" into decisionmaking contexts (e.g., the lowest rungs of Arnstein's ladder of citizen participation, 1969), to encourage practitioners and researchers to think more holistically about long-term inclusion of diverse roles, perspectives, and voices, stakes, and ownership (Quick and Feldman 2011, p 272). This may include adopting alternative methods of participation beyond community meetings, such as: storytelling, advocacy and translation, and documentation of existing community activities (Roberts 2018 pp 10-14; 2020 pp 12-14; Ryberg Webster 2017, pp 19-20).

In research, emphasis on long-term inclusion addresses the challenges of sustained and non-cosmetic stakeholder involvement in planning processes, as well as potentially paternalistic tensions between "expert" and local/practitioner knowledge (Roberts and Kelly 2019). Roberts and Kelly explain how the process of "remixing" roles of practitioners and experts in planning for the historical preservation of Black freedom colonies in Texas helped center the original settlements descendents, while avoiding appropriation of their voices or dominance of expert knowledge. Describing the process of preparing to facilitate descendents' authentic storytelling and the relationship between expert training and personal experience, Roberts says: "I ... accessed memories of Black church services I had attended as a child when sampling, looping, and layering the testimony service structure, relationship building, ethnography, and public education" (Roberts and Kelly 2019, p 307).

\subsection{Track progress using appropriate metrics}

SES metrics used to site and determining planning decisions must include equity as the driving force. For example, in the wake of the 2014 Ferguson uprising against racial injustice (triggered by police murder of Michael Brown), St. Louis, Missouri conducted an Equity Indicators report to quantify racial inequities in the city across 72 measures. The metrics of evaluation reflect the Ferguson Commission Report (Ferguson Commission 2015) and outline three categories: Youth at the Center, Opportunity to Thrive, and Justice for All (City of St. Louis 2018). This is a great first step and effort to incorporate equity into decision-making processes. Unfortunately, since the report's release in 2018, 
there have been no updates provided by St. Louis on the status or actions the city is taking to address the inequities uncovered in the report. Interestingly, St. Louis is part of a larger Equity Indicators tool developed by the City University of New York that includes Dallas, Texas, Oakland, California, Tulsa, Oklahoma, and Pittsburg, Pennsylvania as their inaugural 100 resilient cities group [equalityindicat ors.org]. The project encompasses six equity categories from education and housing to the economy. Establishing baseline metrics to identify specific institutional needs is a great first step to addressing inequalities in planning, but cities have to follow up with specific actions and changes in decisionmaking processes and the valuation of those decisions to truly address environmental inequities.

\section{Conclusions: making connections between what we see, what we know, and what we do}

In this perspective, we reflect on the current and ongoing crises of COVID-19, the anti-racism protests that have reshaped this year, and their relationship to parks and open space. The perspective makes connections between three components: a record of visual observations from the dual crisis, connections to research on the racialization of space, and emerging action principles for improving inclusion in socio-ecological practice in urban areas. The "Stepwise Approach" to relationships between SES and race offers four entry points. The first is one of the most common starting points in both environmental justice and SES practice and research: understanding the uneven spatial distribution of hazards and amenities. An example of this is the over-siting of environmental hazards near communities of color, and the over-siting of environmental goods like well-maintained parks, trails, and green spaces in predominantly white neighborhoods. Step two's entry point is the recognition of green, open spaces and other planning that fall on a spectrum of quality. The third entry point recognizes the way people, and in particular Black people, are surveilled and policed at higher rates with far more serious consequences in these spaces. Our last step expands into the creation of racialized and exclusionary spaces that allow for the policing, disparate amenities or services and inequitable distribution of these spaces in the first place. The objective of the stepwise approach is to assist scholars and practitioners in identifying the next level of anti-racist systems thinking required to make real changes in decision-making processes. Based on the stepwise approach, the action principles presented in the manuscript deemphasize narrow urbanist agendas-such as suggesting taking the "opportunity" of COVID-19 to put "more parks" in Black or poor neighborhoods. Instead, the principles emphasize the importance of shifting processes of power: inclusion, representation, and evaluation, which require long-term engagement and trust-building with communities.

To conclude, this approach is by no means a single solution to addressing the racial inequities in open and green space that COVID-19 and BLM have so profoundly exposed. Nor is it without flaws. What this perspective is, is a call to action and a preliminary step to provide pathways forward in urban SES research and practice through environmental and social justice frameworks.

\section{References}

Agyeman J, Evans B (2004) 'Just sustainability': the emerging discourse of environmental justice in Britain? Geogr J 170(2):155-164

Allen D, Lawhon M, Pierce J (2018) Placing race: on the resonance of place with black geographies. Prog Hum Geogr 43(6):1001-1019. https://doi.org/10.1177/0309132518803775

Anguelovski I (2016) From toxic sites to parks as (green) LULUs? New challenges of inequity, privilege, gentrification, and exclusion for urban environmental justice. J Plan Lit 31(1):23-36. https://doi. org/10.1177/0885412215610491

Arnstein SR (1969) A ladder of citizen participation. J Am Inst Plan 35(4):216-224. https://doi.org/10.1080/01944366908977225

Badger E (2020) The pandemic has pushed aside city planning rules. But to whose benefit? The New York Times. The Upshot. https:// www.nytimes.com/2020/07/20/upshot/pandemic-city-planninginequality.html. Accessed 20 July 2020

Bates L, Towne SA, Jordan CP, Lelliott KL, Towne SA, Jordan CP, Lelliott KL et al (2018) Race and spatial imaginary: planning otherwise/introduction: what shakes loose when we imagine otherwise/she made the vision true: a journey toward recognition and belonging/isha black or isha white? Racial identity and spatial development in Warren County, NC/Colonial City design lives here: questioning planning education's dominant imaginaries/ say its name - planning is the white spatial imaginary, or reading McKittrick and woods as planning text/Wakanda! take the wheel! visions of a black green city/if I built the world, imagine that: reflecting on world building practices in black los angeles/is Honolulu a Hawaiian place? decolonizing cities and the redefinition of spatial legitimacy/interpretations \& imaginaries: toward an instrumental black planning history. Plan Theory Pract 19(2):254288. https://doi.org/10.1080/14649357.2018.1456816

Beck B (2020) Policing gentrification: stops and low-level arrests during demographic change and real estate reinvestment. City Commun 19(1):245-272. https://doi.org/10.1111/cico.12473

Bittel J (2020) People called police on this black birdwatcher so many times that he posted custom signs to explain his hobby. Washington Post. https://www.washingtonpost.com/science/2020/06/05/ people-called-police-this-black-birdwatcher-so-many-times -that-he-posted-custom-signs-explain-his-hobby/. Accessed 5 June 2020

Boone CG, Buckley GL, Grove JM, Sister C (2009) Parks and people: an environmental justice inquiry in Baltimore. Maryland Ann Assoc Am Geogr 99(4):767-787. https://doi.org/10.1080/00045 600903102949

Branas CC, Cheney RA, MacDonald JM, Tam VW, Jackson TD, Have TRT (2011) A difference-in-differences analysis of health, safety, 
and greening vacant urban space. Am J Epidemiol 174(11):12961306. https://doi.org/10.1093/aje/kwr273

Brand AL, Miller C (2020) Tomorrow I'll be at the table: black geographies and urban planning: a review of the literature. J Plann Lit 35(4):460-474. https://doi.org/10.1177/0885412220928575

Bronin S (2020). Coronavirus is a reminder to value parks and public spaces, opinion. https://www.inquirer.com. Accessed 26 March 2020. Commentary, opinion, coronavirus, health. https://www. inquirer.com/opinion/commentary/coronavirus-shutdowns-parks -outdoors-philadelphia-20200326.html.

Bullard RD (1997) Environmental justice for all. In: Bullard RD (ed) Unequal protection: environmental justice and communities of color. Sierra Club Books, San Francisco

Burns K (2020) Why police often single out trans people for violence." Vox. https://www.vox.com/identities/2020/6/23/21295432/polic e-black-trans-people-violence. Accessed 23 June 2020

Butler P (2017) Chokehold: policing black men. The New Press, New York

Byrne J, Wolch J (2009) Nature, race, and parks: past research and future directions for geographic research. Prog Hum Geogr 33(6):743-765. https://doi.org/10.1177/0309132509103156

Carr SJ (2014) The topography of wellness: mechanisms, metrics, and models of health in the urban landscape. Dissertation, Berkeley, CA, University of California, Berkeley. https://escholarship.org/ uc/item/8cg2t 860

CDC (2020) Coronavirus disease 2019 (COVID-19). Centers for disease control and prevention. https://www.cdc.gov/coronaviru s/2019-ncov/need-extra-precautions/racial-ethnic-minorities.html. Accessed 11 February 2020

Chiesura A (2004) The role of urban parks for the sustainable city. Landsc Urban Plan 68(1):129-138. https://doi.org/10.1016/j.landu rbplan.2003.08.003

De Vries S, Verheij R, Groenenwegen P, Spreeuwenberg P (2003) "Natural environments-healthy environments? An exploratory analysis of the relationship between greenspace and health. Environ Plan 35(10): 1717-1731

DiMento JFC, Ellis C (2012) Changing lanes: visions and histories of urban freeways, 1 st edn. The MIT Press, Cambridge

Douglas I, Champion M, Clancy J, Haley D, de Souza ML, Morrison K, Scott A et al (2020) The COVID-19 pandemic: local to global implications as perceived by urban ecologists. Socio Ecol Pract Res 2(3):217-228. https://doi.org/10.1007/s42532-020-00067-y

Dwyer OJ, Jones JP (2000) White socio-spatial epistemology Soc Cult Geogr 1(2):209-222. https://doi.org/10.1080/146493600200102 11

Edwards MM, Bates LK (2011) Planning's core curriculum: knowledge, practice, and implementation. J Plan Educ Res 31(2):172183. https://doi.org/10.1177/0739456X11398043

Eisenman TS (2013) Frederick law olmsted, green infrastructure, and the evolving city. J Plan Hist 12(4):287-311. https://doi. org/10.1177/1538513212474227

Fayyad, A. 2017. The criminalization of gentrifying neighborhoods. The Atlantic (blog). https://www.theatlantic.com/politics/archi ve/2017/12/the-criminalization-of-gentrifying-neighborho ods/548837/. Accessed 20 December 2017

Commission F (2015) Forward through Ferguson; a path toward racial equity. St. Louis Louis Public Library, Ferguson. forwardthroughf erguson.org

Fisher T (2010) Frederick law olmsted and the campaign for public health. Places J. https://doi.org/10.22269/101115

Fraser N (1995) From redistribution to recognition? Dilemmas of justice in a 'post-socialist' age. New Left Rev 66:68-149

Frazier C (2019) Repurposing queens: excavating a black feminist eco-ethic in a time of ecological peril. Northwestern University, Evanston
Frazier CM (2016) Troubling ecology: WangechiMutu, Octavia Butler, and black feminist interventions in environmentalism. CritEthn Stud 2(1):40. https://doi.org/10.5749/jcritethns tud.2.1.0040

Frazier C (2018) Thinking red, wounds, and fungi in Wangechi Muitu's EcoArt. In: Heuer CP, Zorach R (eds) Ecologies, agents, terrains. Yale University Press, pp 167-195

Fullilove MT (2001) Root shock: the consequences of African American dispossession. J Urban Health: Bull NY Acad Med 78(1):7280. https://doi.org/10.1093/jurban/78.1.72

Fullilove MT (2020) From 'root shock' to 'main street': for a biopsychosocial urban psychology. J Urban Regen Renew 13(3):251-256

Garcia SE (2020) Where did BIPOC come from? The New York Times. Style. https://www.nytimes.com/article/what-is-bipoc.html. Accessed 17 June 2020

Glotzer P (2020) Developing spaces of exclusion. In: Presented at the segregation and resistance in America's urban landscapes GLS symposium 2020 virtual series. Dumbarton Oaks Research Library and Collection, Harvard University. https://www.doaks .org/research/garden-landscape/scholarly-activities/segregatio $\mathrm{n}$-and-resistance-in-americas-urban-landscapes. Accessed 20 July 2020

Gobster PH, Westphal LM (eds) (1998) People and the river: perception and use of Chicago waterways for recreation. DOI National Park Service, Chicago

Gobster PH (2002) Managing Urban Parks for a Racially and Ethnically Diverse Clientele. Leisure Sci 24(2):143-159. https://doi. org/10.1080/01490400252900121

Greenlee AJ, Jackson A, Garcia-Zambrana I, Lee CA, Chrisinger B (2018) Where are we going? Where have we been?: the climate for diversity within urban planning educational programs. J Plan Educ Res 27(7):917-943. https://doi.org/10.1177/0739456X18815740

Heathcott J (2005) 'The whole city is our laboratory': Harland Bartholomew and the production of urban knowledge. J Plan Hist 4(4):322-355. https://doi.org/10.1177/1538513205282131

Heynen N, Perkins HA, Roy P (2006) The political ecology of uneven urban green space the impact of political economy on race and ethnicity in producing environmental inequality in Milwaukee. Urban Aff Rev 42(1):3-25. https://doi.org/10.1177/1078087406 290729

Holifield R (2013) Defining environmental justice and environmental racism. Urban Geogr 22(1):78-90. https://doi. org/10.2747/0272-3638.22.1.78

Immergluck D, Balan T (2018) Sustainable for whom? Green urban development, environmental gentrification, and the Atlanta Beltline. Urban Geogr 39(4):546-562. https://doi.org/10.1080/02723 638.2017.1360041

Jeffery A (2020) Photos: in Las Vegas, a parking lot hosts homeless people during coronavirus outbreak. CNBC. https://www.cnbc. com/2020/04/15/photos-las-vegas-parking-lot-hosts-homelesspeople-during-coronavirus.html. Accessed Apr 152020.

Kaplan EA (2020) Opinionleveryone's an antiracist. Now what? The New York Times. Opinion. https://www.nytimes.com/2020/07/06/ opinion/antiracism-what-comes-next.html. Accessed 6 July 2020

Kearney MS, Pardue L (2020) Exposure on the job. Middle Class Memos. Brookings Institute. https://www.brookings.edu/resea rch/exposure-on-the-job/.

King ML Jr (1967) Where do we go from here: chaos or community? Beacin Press, Boston

Kochhar R (2020) Unemployment rose higher in three months of covid-19 than it did in two years of the great recession. FactTankPew Research Center (blog). https://www.pewresearch.org/facttank/2020/06/11/unemployment-rose-higher-in-three-month s-of-covid-19-than-it-did-in-two-years-of-the-great-recession/. Accessed 11 June 2020 
Kondo MC, Low SC, Henning J, Branas CC (2015) The impact of green stormwater infrastructure installation on surrounding health and safety. Am J Public Health 105(3):e114-e121. https://doi. org/10.2105/AJPH.2014.302314

Kuo FE (2001) Coping with poverty: impacts of environment and attention in the innter city. Environ Behav 33(1):5-34

Landry SM, Chakraborty J (2009) Street trees and equity: evaluating the spatial distribution of an urban amenity. Environ Plan A: Econ Space 41(11):2651-2670. https://doi.org/10.1068/a41236

Linton C (2020) Field hospital that treated coronavirus patients in central park to close. https://www.cbsnews.com/news/field-hospi tal-that-treated-coronavirus-patients-in-central-park-to-close/. Accessed 2 May 2020

Lipsitz G (2007) The racialization of space and the spatialization of race theorizing the hidden architecture of landscape. Landsc J 26(1):10-23. https://doi.org/10.3368/lj.26.1.10

Locke, D., B. Hall, JM Grove, S.T.A. Pickett, L.A. Ogden, C. Aoki, C. G. Boone, and J.P.M. O’Neil-Dunne. 2020. Residential housing segregation and urban tree canopy in 37 US cities. SocArXiv. https://doi.org/10.31235/osf.io/97zcs

Lyons T, Krüsi A, Pierre L, Small W, Shannon K (2017) The impact of construction and gentrification on an outdoor trans sex work environment: violence, displacement and policing. Sexualities 20(8):881-903. https://doi.org/10.1177/1363460716676990

Maas J, Verheij RA, Groenewegen PP, De Vries S, Spreeuwenberg $P$ (2006) Green space, urbanity, and health: how strong is the relation? J EpidemiolCommun Health 60(7):587-592. https://doi. org/10.1136/jech.2005.043125

Maharawal MM (2017) Black lives matter, gentrification and the security state in the san Francisco Bay area". Anthropol Theory 17(3):338-364. https://doi.org/10.1177/1463499617732501

McCammack B (2019) Landscapes of hope: nature and the great migration in chicago. In: Presented at the black and brown lives in green spaces: race and place in urban America, metropolitan planning council, dusable museum of African American history, Chicago, IL, July 25. https://www.metroplanning.org/events/event/504

McHarg I (1969) Design with nature. Natural History Press, Garden City

Forester J, McKibbon G (2020) Beyond blame: leadership, collaboration and compassion in the time of COVID-19. Socio Ecol Pract Res 2(3):205-216. https://doi.org/10.1007/s42532-020-00057-0

McKittrick K (2011) On plantations, prisons, and a black sense of place. Soc Cult Geogr 12(8):947-963. https://doi.org/10.1080/14649 365.2011.624280

McKittrick K, Woods C (eds) (2007) Black geographies and the politics of place. South End Press, Toronto, Cambridge

Mell I (2020) Coronavirus: urban parks can be a lifeline-if we respect lockdown rules. The Conversation, March. https://theconversation .com/coronavirus-urban-parks-can-be-a-lifeline-if-we-respectlockdown-rules-134185

Pellow DN (2016) Toward a critical environmental justice studies: black lives matter as an environmental justice challenge. Du Bois Rev: SocSci Res Race 13(2):221-236. https://doi.org/10.1017/ S1742058X1600014X

Poon L (2020) The racial injustice of American highways. Bloomberg.Com. https://www.bloomberg.com/news/articles/2020-06-03/ what-highways-mean-to-the-george-floyd-protesters. Accessed 3 June 2020.

Quick KS, Feldman MS (2011) Distinguishing participation and inclusion. J Plan Educ Res 31(3):272-290. https://doi. org/10.1177/0739456X11410979

Rigolon A, Németh J (2018) What shapes uneven access to urban amenities? Thick injustice and the legacy of racial discrimination in Denver's parks. J Plan Educ Res. 10.1177/0739456X18789251
Roberts A, Zamore S (2020) Black in nature. Milwaukee Courier Weekly Newspaper (blog). https://milwaukeecourieronline.com/ index.php/2020/06/10/black-in-nature/. 10 June 2020

Roberts AR (2018) Performance as place preservation: the role of storytelling in the formation of shankleville community's black counterpublics. J CommunArchaeolHerit 5(3):146-165. https:// doi.org/10.1080/20518196.2018.1480002

Roberts AR (2020) Preservation without representation: making CLG programs vehicles for inclusive leadership, historic preservation, and engagement". Societies 10(3):60. https://doi.org/10.3390/ soc 10030060

Roberts AR, Kelly G (2019) Remixing as praxis. J Am Plan Assoc 85(3):301-320. https://doi.org/10.1080/01944363.2019.1622439

Rodela R, Bregt AK, Ligtenberg A, Pérez-Soba M, Verweij P (2017) The social side of spatial decision support systems: investigating knowledge integration and learning. Environ Sci Policy 76:177184. https://doi.org/10.1016/j.envsci.2017.06.015

Ryberg Webster S (2017) Beyond rust and Rockefeller: preserving Cleveland's African American heritage. Preserv Educ Res 9:7. https://engagedscholarship.csuohio.edu/urban_facpub/1510?utm_ source $=$ engagedscholarship.csuohio.edu $\% 2$ Furban_facpu b\%2F1510\&utm_medium $=$ PDF\&utm_campaign $=$ PDFCoverPa ges

Sadler J, Bates A, Hale J (2010) Bringing cities alive: the importance of urban green spaces for people and biodiversity. In: Gaston $\mathrm{K}$ (ed) Urban ecology. Cambridge University Press, Cambridge, pp 230-260

Scannell L, Gifford R (2010) Defining place attachment: a tripartite organizing framework. J Environ Psychol 30(1):1-10. https://doi. org/10.1016/j.jenvp.2009.09.006

Schlosberg D (2007) Defining environmental justice: theories, movements, and nature. Oxford University Press, Oxford

Shi L (2020) Beyond flood risk reduction: how can green infrastructure advance both social justice and regional impact? Socio Ecol Pract Res. https://doi.org/10.1007/s42532-020-00065-0

Sister C, Wolch J, Wilson J (2010) Got green? Addressing environmental justice in park provision. GeoJournal 75(3):229-248. https:// doi.org/10.1007/s10708-009-9303-8

Solecki WD, Welch JM (1995) Urban parks: green spaces or green walls? Landsc Urban Plan 32(2):93-106. https://doi. org/10.1016/0169-2046(94)00193-7

Southall, A. 2020. Scrutiny of social-distance policing as 35 of 40 arrested are black. The New York Times. New York. https://www. nytimes.com/2020/05/07/nyregion/nypd-social-distancing-racecoronavirus.html. Accessed 7 May 2020

Steiner F, Fleming B (2019) Design with nature at 50: its enduring significance to socio-ecological practice and research in the twenty-first century. Socio Ecol Pract Res 1(3):173-177. https:// doi.org/10.1007/s42532-019-00035-1

City of St. Louis (2018) Equity Indicators Baseline Report. MO: Office of the Mayor, St. Louis. https://www.stlouismo.gov/government/ departments/mayor/initiatives/resilience/equity/documents/equit y-indicators-baseline-report.cfm

Su JG, Jerrett M, de Nazelle A, Wolch J (2011) Does exposure to air pollution in urban parks have socioeconomic, racial or ethnic gradients? Environ Res 111(3):319-328. https://doi.org/10.1016/j. envres.2011.01.002

Taylor, D.E. 2002. Race, class, gender, and American environmentalism. USDA forest service-general technical report PNW, no. Apr, 1-51.

Thomas D (2020) 'Safe streets' are not safe for black lives. Bloomberg. Com. https://www.bloomberg.com/news/articles/2020-06-08/safe-streets-are-not-safe-for-black-lives. Accessed 8 June 2020

Toomey, AlyssaToomey, News 4. 2020. Foul-smelling chicken farm has residents frustrated in north St. Louis. KMOV.com. KMOV. https ://www.kmov.com/news/foul-smelling-chicken-farm-has-resid 
ents-frustrated-in-north-st-louis/article_db572b06-b725-11eabaf8-63df692cb08d.html

Ulrich RS (1986) Human responses to vegetation and landscapes. Landsc Urban Plan 13:29-44. https://doi.org/10.1016/01692046(86)90005-8

Vaughan KB, Kaczynski AT, Wilhelm Stanis SA, Besenyi GM, Bergstrom R, Heinrich KM (2013) Exploring the distribution of park availability, features, and quality across Kansas City, Missouri by income and race/ethnicity: an environmental justice investigation. Ann Behav Med 45(supp_1):S28-S38. https://doi.org/10.1007/ s12160-012-9425-y

White MP, Alcock I, Wheeler BW, Depledge MH (2013) Would you be happier living in a greener urban area? A fixed-effects analysis of panel data. PsycholSci 24(6):920-928. https://doi. org/10.1177/0956797612464659

Wolch JR, Byrne J, Newell JP (2014) Urban green space, public health, and environmental justice: the challenge of making cities 'just green enough.' Landsc Urban Plan 125:234-244. https://doi. org/10.1016/j.landurbplan.2014.01.017

Xiang W-N (2019) Ecopracticology: the study of socio-ecological practice. Socio Ecol Pract Res 1(1):7-14. https://doi.org/10.1007/ s42532-019-00006-6

Xiang W-N (2020) Envisioning alternative futures of socio-ecological practice; navigating an uncertain world with a compass of scenarios. Socio Ecol Pract Res 2:1-3. https://doi.org/10.1007/s4253 2-020-00063-2

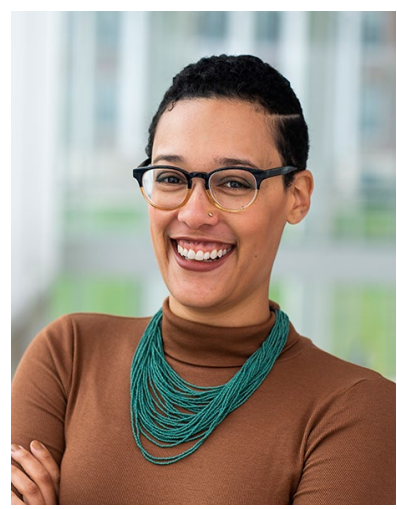

Fushcia-Ann Hoover is a postdoctoral associate at the National Socio-Environmental Synthesis Center in Annapolis, MD. Her research explores the relationships between people, green infrastructure and urban hydrologic systems through an environmental justice lens. Her work intersects with health, black ecofeminism and geographies.

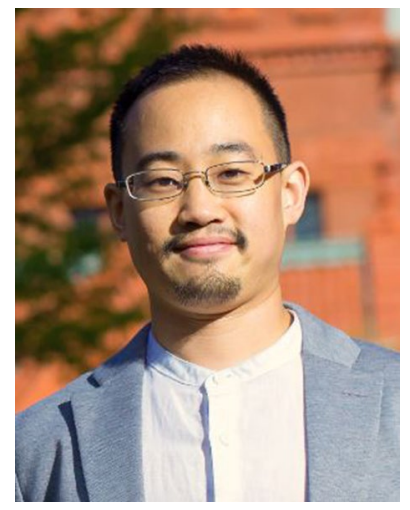

Theodore Lim is an assistant professor of Urban Affairs and Planning at Virginia Tech. His research and teaching focus on the connections between land, water, infrastructure, and people in sustainability planning. In addition to academic scholarship, he has also worked in the public health, civil engineering, and agricultural technology sectors. 